\title{
The Ontology of Technology Beyond Anthropocentrism and Determinism: The Role of Technologies in the Constitution of the (post)Anthropocene World
}

\section{Vincent Blok ${ }^{1}$}

Accepted: 6 January 2022

(c) The Author(s) 2022

\begin{abstract}
Because climate change can be seen as the blind spot of contemporary philosophy of technology, while the destructive side effects of technological progress are no longer deniable, this article reflects on the role of technologies in the constitution of the (post)Anthropocene world. Our first hypothesis is that humanity is not the primary agent involved in world-production, but concrete technologies. Our second hypothesis is that technological inventions at an ontic level have an ontological impact and constitutes world. As we object to classical philosophers of technology like Ihde and Heidegger, we will sketch the progressive contribution of our conceptuality to understand the role of technology in the Anthropocene world. Our third hypothesis is that technology has emancipatory potential and in this respect, can inaugurate a post-Anthropocene World. We consider these three hypotheses to develop a philosophical account of the ontology of technology beyond an abstract and deterministic understanding. This concept enables us to philosophically reflect on the role of technology in the Anthropocene World in general, and its contribution to the transition to the post-Anthropocene World in particular.
\end{abstract}

Keywords Anthropocene $\cdot$ Technology $\cdot$ Ontology $\cdot$ World $\cdot$ Anthropocentrism

\section{Introduction}

The world-historical significance of climate change consists in the fact that it disrupts the climate stability of our being-in-the-world in the Holocene-i.e. the geological era of the last 11.700 years - and inaugurates a new geological era of climate instability; the Anthropocene World. Emerging with the industrial revolution and accelerating after the second World War, the face of the Earth transformed under the influence of techno-scientific prog-

Vincent Blok

vincent.blok@wur.nl

1 Philosophy Group, Wageningen University, Hollandseweg 1, 6707 Wageningen, KN, The Netherlands 
ress, resulting in a global interior milieu in which technological development and natural development become intertwined (Steffen et al., 2015). In the Anthropocene, the natural environment can no longer be conceived without technological cultivation, preservation and development, while climate change makes it impossible to conceptualize our technological society without the natural environment on which it depends. As I have elaborated in an earlier contribution, the advent of the Anthropocene does not imply the end of the world (Blok, 2021a). On the contrary, it concerns a new world, i.e. a new meaningful constellation in which we are intentionally involved and know how to deal with other human and nonhuman beings in the world. In this new world, the climatic optimum of our being-in-theHolocene is disrupted (Blok, 2022).

Although climate change can be seen as the blind spot of contemporary philosophy of technology (Lemmens et al., 2017), the destructive side effects of technological progress call for philosophical reflection on the role of technology in the Anthropocene World. Because our technological societies are using significant more natural resources then the planetary ecosystem can provide, a new phase in the Anthropocene is called for in which technology - we can think of a sulfuric acid shield that is released into the atmosphere by humans to reflect sun rays, or by mounting large mirrors on satellites - ensures the sustainability of Earth's life-support system for human and non-human life on Earth. In this regard, the Anthropocene World does not only describe the time of climate change as side effect of technoscientific progress, but also calls for the production of a new post-Anthropocene World in which humanity takes responsibility for the sustainability of the life support systems of planet Earth. Clive Hamilton for instance argues: "Once humans separated from other creatures and began deliberately to use their world-making powers to modify their environments they assumed responsibility for natural systems and other animals. But now, in the Anthropocene, the fate of the Earth has become entwined with the fate of humans and our responsibility is of a new kind, risen to another level. Before our own welfare, our virtues, and our duties to one another, our inescapable responsibility for the Earth defines us as moral beings" (Hamilton, 2017: 52). The Anthropocene World calls for human worldmaking powers to constitute this post-Anthropocene World in which humanity takes care of the sustainability of the life support systems of planet Earth.

This raises the question of what the role of humanity actually is in the production of the post-Anthropocene World. Philosophy of technology always concerns the relation between technology and world, whether the starting point of this relation is found in beings that mediate and shape the world at an ontic level (Ihde, 2012), or in the whole of being that mediates and shapes the world at an ontological level, for instance the mutual challenging (Enframing) of humanity and nature as standing-reserve for our exploitation in the age of technology (Heidegger, 1977). Our first hypothesis is that humanity is not the primary agent involved in world-production $(\S 1)$. Our second hypothesis is that technological inventions at an ontic level have an ontological impact and constitutes world at an ontological level (§2.1). This hypothesis seems to be inconsistent with Heidegger’s intuition, as he argues that "the essence of technology is by no means anything technological" (Heidegger, 1977: 4). As we indeed object to both Ihde and Heidegger in this regard, we will sketch the progressive contribution of our conceptuality to understand the role of technology in the Anthropocene world (\$2.2). But if not humans but technology itself produces World, do we then not commit to a passive role of humanity as enslaved by the technological World of the Anthropocene, in which no sign of a post-Anthropocene World can be found? Notwith- 
standing the first two hypotheses, our third hypothesis is that technology has emancipatory potential and in this respect, can inaugurate a post-Anthropocene World ( 33$)$. In this article, we consider these three hypotheses to develop a philosophical account of the ontology of technology beyond an abstract and deterministic understanding. This concept enables us to philosophically reflect on the role of technology in the Anthropocene World in general, and its contribution to the transition to the post-Anthropocene World in particular.

\subsection{Questioning the World-Making Capacity of Humanity}

If we look at the Anthropocene World, it seems to be self-evident that human power is its distinguishing characteristic: "The human imprint on the global environment has now become so large and active that it rivals some of the great forces of Nature in its impact on the functioning of the Earth system" (Steffen et al., 2011: 843). Contrary to the Holocene, in which the geological development was determined by blind natural forces, the Anthropocene is determined by an additional geological power that rivals with these natural forces, namely humanity. Human power transformed the Earth system since the industrial revolution, by upgrading human life to the technological societies we currently live in while downgrading the conditions of non-human life on Earth, which has led to the human induced climate change we face today. According to ecomodernists, humanity is also expected to manage and control the Earth system, which results in the future sustainability of planet Earth due to human control (Ellis, 2011). Others argue that the Anthropocene indeed upended the relation between humanity and nature, which enforces us to reflect on the new role of humanity. For them, however, human control is no longer feasible as nature's forces turn out to be untameable in the Anthropocene and rival with human forces. They see the role of humankind in taking care of the Earth (Hamilton, 2017).

We don't want to discuss whether ecomodernists are right in their prognosis of the future state of the planet and whether control is feasible in light of 'nature's revenge for climate change' (Pearce, 2007), or leaves us with an 'inhabitable Earth' (Wallace-Wells, 2019). The point of departure of both proponents and opponents of human control is found in the central role of humanity. It is the technological power of humanity that is part of the problem-i.e. climate change - but could be part of the solution if we accept our responsibility for the future of the Earth. Contrary to the normative anthropocentrism of ecomodernism, the idea that only humans have moral standing and can exploit the natural world, Hamilton argues for instance for teleological anthropocentrism, the idea that humans have the factual task to take care of the Earth. Care for the planet is found in the world-making capacity of human kind (Hamilton, 2017: 56; 62). The world-historical significance of climate change does not only consist in the inauguration of the Anthropocene World, but also reveals humanity as world-making power. And if we ask for a post-Anthropocene World in which humanity takes responsibility for the sustainability of the life support systems of planet Earth, we can argue that the primary responsibility of humanity consists in such a world-production. We briefly consult Hamilton's argument to understand the role of humanity in world-production.

With world, Hamilton means the environment of social and material practices (Hamilton, 2017: 62) in which we are always already intentionally involved and which constitutes a meaningful interior milieu of meaning (Blok, 2022). The Anthropocene is such a new worldin-the-making that is discovered by the Earth System Sciences: "It's worth noting that the notion of a global climate (one of the components of the Earth System) became widely 
accepted by scientists only after World War II. Except for a few speculative commentaries, 'climate' had previously been considered a local and regional phenomenon" (Hamilton, 2017: 63). World does not concern a new object — e.g. climate — but the meaning - e.g. local, global — of this object in a new epoch, the whole of being which goes beyond the so called sum of its parts (Hamilton, 2017: 11-12).

Although Hamilton's conception of world moves beyond the flat ontology of earthly objects (Latour, 2016) ${ }^{1}$ and introduces an ontological concept of World as global environment (Blok, 2021a), we can criticize his conceptualization of World as he clearly mixes up the ontic and ontological level of analysis. He for instance argues that Earth System Sciences discover a new "object"-e.g. Earth - while Earth is at the same time conceived "beyond the sum of its parts", i.e. not as object at the ontic level but as the whole of being at an ontological level (Hamilton, 2017: 11-12). Because Hamilton is ambiguous in his analysis ${ }^{2}$, we here clearly distinguish between objects at an ontic level, and the World of the Anthropocene at an ontological level. We define World as the ontological pattern of meaning - think of oppositions like nature-technology, matter-form, freedom-necessity etc. - that structures our relation to ourselves and to other human and non-human beings, i.e. natural and social practices and values. Does humanity make the world at ontological level, and can we expect humanity to make the post-Anthropocene World in times of climate change?

The Anthropocene World is not so much made by humans according to a deliberate plan, but "grows up behind our backs" through our ideas and activities (Hamilton, 2017: 63). Hamilton is quite ambiguous if it comes to the role of humankind, as he on the one hand argues that world-making is the unique human characteristic, but at the same time associates this capacity with the particular epoch of the Anthropocene. It is precisely in the Anthropocene World, that humanity is given "the central place with a unique transformative role on Earth" (Hamilton, 2017: 66). Before the Anthropocene World, humanity appeared not as creator but as ens creatum for instance, which means that the world-making capacity is not a universal characteristic of humanity as such, but only of humanity in the Anthropocene World. In the Anthropocene, humankind is the creator of a new world which is limited by the countervailing power of nature, by the untameable Earth (Hamilton, 2017: 63). But to the extent that humanity as world-making capacity only emerged in the Anthropocene World, we can argue that the 'making' of the Anthropocene World in contrast with the Holocene World is itself not the product of humanity. ${ }^{3}$ The Anthropocene World is not only not deliberately planned by humans as Hamilton would have it, but not produced by humans at all. World grows up behind our backs in the literal sense of the word (see $\$ 2$ ).

In response, Hamilton could argue that technology is of decisive importance in the Anthropocene, and that technological invention is de defining quality of human beings as world-making creatures (Hamilton, 2017: 73). For him, techno-industrialism is the cause of the Anthropocene world (Hamilton, 2017: 65), but remains a human category and embedded in humanities' world-making capacity. But even if we accept with Hamilton the role of

\footnotetext{
${ }^{1}$ See for instance Hamilton's critical discussion of Latour's flat ontology (2017: 101-102).

${ }^{2}$ As I elaborated in another contribution, this ambiguity might be explained by Hamilton's scienticsm, i.e. his dependency on Earth systems sciences as primary point of access to the World (Hamilton, 2017: 21; 63; Blok 2022).

3 If humanity 'made' the Anthropocene World, then humanity as world making capacity existed already before the Anthropocene World, before the act of making this World. And if it already existed before human being-in-the-Anthropocene-world, it cannot concern a unique characteristic of humanity in the Anthropocene anymore.
} 
technology in world-production, we do not have to accept the central role of humanity in world-production. Philosophers like Marx already questioned whether technological evolution is best understood from a human perspective, or is better understood like natural evolution (Marx, 1973). In philosophy of technology, for instance, technological evolution is much more seen as determined by previous stages of development, interdependencies with other technological developments, and by intrinsic universal technical tendencies which are independent of humanity but are operationalized in concrete technologies in relation to particular cultural and environmental settings (Leroi-Gourhan, 1945; Simondon, 2017; Stiegler, 1998).

Also for classical philosophers of technology like Heidegger, technology is not primarily a human category. In the introduction, we encountered already an argument why humanity is not primarily the producer of World. The Anthropocene World can be seen as a concrete experience of the environment as resource which is challenged-forth to stand in reserve as potential resource for human needs, whilst humans are challenged-forth as managers of these resources. But if the Anthropocene offers a concrete experience of the essence of technology (Zwier \& Blok, 2017), while according to Heidegger, the essence of technology is nothing human (Heidegger, 1977: 4), it is questionable whether humanity is the primary agent involved in world-production, and can be held responsible for the production of the post-Anthropocene World. According to Heidegger, the essence of technology constitutes the World as resource and human beings as managers of these resources in the techno-industrial World, and therefore, human beings cannot be seen as subjects of world-making, as they are included in this world in which they primarily appear as world-maker or producer. According to a Heideggerian perspective, it is the essence of technology as Enframing that makes the techno-industrial World of the Anthropocene, not humanity. What is more, from a Heideggerian perspective, we could argue that the idea of humanity as world-making power only emerges in the Anthropocene world, as only in this world of enframing humans appear in terms of producers and makers of world. Human beings are not the subject of the making of the Anthropocene World, but in the techno-industrial World of the Anthropocene, humanity appears as world-maker.

Are we, as a consequence of the rejection of humanity as world-making power, convinced that this world is produced by the essence of technology, as Heidegger would argue? On the one hand, the role of technology in the Anthropocene World is not limited to the emergence of new technologies at an ontic level, but concerns the whole of being in which human beings are included. The experience of global warming in the Anthropocene can make this concrete. The experience of global warming is primarily the experience of a global phenomenon we were not aware of in previous times; the climate in which we self-evidently live and on which our being-in-the-world depends. This climate concerns the whole of being in the sense that in the age of global warming, there is no position possible outside of it; whereas in earlier ages, it was possible to externalize waste to the environment, we nowadays realize that every externalization returns like a boomerang and impacts Earth's life-support systems (Blok, 2017). In other words, the Anthropocene is not only an ontic phenomenon, i.e. a geological epoch that started at a particular moment in time (for instance the Trinity test on 16 July 1945) and can be established by a community of geologists. It concerns also and more significantly an ontological phenomenon, namely the disruption of the way in which reality as a whole appears - the world as challenged forth - and the way human being is responsive to this new reality - human beings as challenged forth - in this new epoch. What is at stake 
in the transition from the Holocene to the Anthropocene, therefore, is an ontological shift of our understanding of the environing world as a whole and of our human responsiveness to this new emerging world (Zwier \& Blok, 2017).

On the other hand, we should be hesitant to accept a Heideggerian explanation of the Anthropocene World. Even if we accept his rejection of humanity as subject of world-making, we should be hesitant to embrace the idea that the essence of technology is the primary subject of world-making of the Anthropocene World. According to Heidegger, the essence of technology (ontological level) is nothing technological (ontic level) (Heidegger, 1977). We are hesitant to accept this, as one can argue that the starting point of the Anthropocene coincides with James Watt's design of the steam engine in 1784 (Crutzen, 2002), while the great acceleration after World War II coincides with new inventions like computerized networks and new long-distance transportation technologies (Steffen et al., 2015). At the same time, we can argue that the actual increase of emissions of these technologies in our technological societies disrupt the Earth system and call for a post-Anthropocene World, i.e. that technology at an ontic level seems to disrupt the World at the ontological level.

So even if we reject Hamilton's idea that humanity is the primary agent involved in world-production based on an Heideggerian argument, this should not induce us to embrace Heidegger's alternative to see the essence of technology as subject of the World of the Anthropocene. For Heidegger, the essence of technology is nothing technological, while we have reason to consider the world-creating and world-destructing capacity of technologies like the steam engine and digital technologies in the next section.

\section{The World-Making Capacity of Technological Inventions}

\subsection{The Ontological Impact of the Invention of the Steam Engine}

In the history of technology, it is observed that technological innovations lead to economic waves, for instance the wave starting around 1845 associated with steam power and technological innovations in the railway industry, or the wave starting around 1900 associated with electricity and innovations like the internal combustion engine (Schumpeter, 1983) (Fig. 1).

The idea that technological innovations lead to economic waves shows that they operate at two levels. At an ontic level, new technologies like the windmill or the steam engine emerge as new artefacts in the world. At a socio-economic level, these artefacts disrupt the

Fig. 1 Schematic presentation of Schumpeterian long waves. GDP, gross domestic product (Hilbert, 2020)

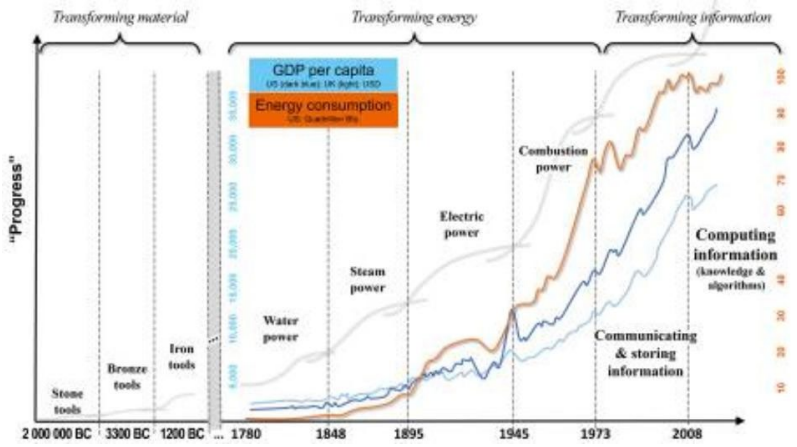


world order that is associated with these technologies; the emergence of the water mill and the accompanying textile industry was embedded in the world order associated with water power, which in turn gave rise to a new world order associated with steam power, in which the steam engine and the accompanying railway industry is embedded etc. (Blok, 2021b). The emergence of the steam train for instance enabled people to travel more easily and quickly from rural areas to the city centre or from the East coast to the West coast and to try their luck there. It also gave rise to cultural phenomena like the Christmas holiday, including Christmas trees, cards and gifts. At the same time, railroads enabled the transport of vast amounts of raw materials to industrial plants and mills to produce the building blocks of industrial societies in the wake of the industrial revolution. As a consequence of this increased social mobility, the urban bourgeoisie grew in size and began to overshoot the nobility in power, number and prestige. A new working class emerged who worked in the factories, but caused also social and political tensions due to unhealthy labour conditions, increased economic inequality and unemployment (Figes, 2019).

Although this example shows how technological inventions like the steam engine change the socio-economic world order, as is argued by philosophers like McLuhan (1964), this world order primarily concerns the new socio-economic meaning of these beings in the world, not the meaning of their being as a whole at an ontological level. With 'ontology', we do not mean an eternal metaphysical idea, but a temporary category that establishes a new meaning of our being-in-the-world, in which the further development of technologies remain embedded. We encounter the ontological impact of the steam engine if we consider that its invention did not only initiate the material and social mobility of resources that resulted in the technological societies we encounter today, but already appeals to reality in its mobility, in its being energetic. Through the invention of the steam engine, beings in the world become accessible in a different manner, namely not as relatively immobile and locally embedded material objects that can be transformed by technology (e.g. stone, bronze, iron), but as relatively mobile and non-local energy (e.g. steam, electricity). We speak of being as mobile and non-local energy in case of the wave associated with steam and not in case of the wave associated with water, because before the invention of electricity, the production and consumption of water power is dependent on a geographic location like a river or lake, while steam power is mobile and non-local (e.g. steam train). What is at stake in this transformation of the appearance of the world is not only the emergence of a new type of beings in the world that didn't exist before, e.g. steam power. It also not only involve the transformation of the socio-economic order of these beings in the world order that begins with the invention of the steam engine, e.g. the physical and social mobility that leads to our industrial society. What is at stake in this transformation is first and foremost the transformation of the appearance of the being of these beings as a whole.

This becomes clear if we consider that the mobility and non-locality of energy is not limited to the steam that powers the steam train. Also the natural and human resources that are transported by train no longer appear as relatively immobile and locally embedded material objects, but as mobile and non-local energy converters; coal appears no longer primarily as material object but as potential converter of water to steam power, like the labourer appears as potential converter of natural clay or shale to bricks etc. On the one hand, natural and human resources appear as converted energy, e.g. water is converted to pressurized steam to power the train, bricks are converted to clay or shale to build houses and city systems, the human subject is converted to the worker who manages the production process of these 
bricks in brick factories etc. On the other hand, natural and human resources appear as energy converters, e.g. the steam engine appears as converter of water to steam power, natural resources like coal appear as converters of energy, workers appear as converters of energy, for instance as workforce in the brick factories. This double meaning of natural and human resources as converted converters characterizes the world at an ontological level since the invention of the steam engine, and concerns the transformation of the appearance of the world as immobile and locally embedded object to the world as converted converter. We speak of an ontological impact, as the invention drives into and pushes (impingere) a new temporarily fixed meaning of the whole of being, namely world as mobile and nonlocal converted converter. ${ }^{4}$

The scope of this new emerging world becomes clear if we take an example. Clay is converted into bricks and these bricks are at the same time converters to build a house. First of all, what these converted converters are converted for belong to the world as converted converter; water is converted for steam, steam is converted for the production of bricks, bricks are converted for the production of factories, factories are converted for the accommodation of larger steam engines, larger steam engines are converted to convert water in a more efficient way etc. All these converted converters belong to the world as converted converter. Second, the natural resources these converted converters are converted from belong to the world as converted converter: the steam engine is dependent on converted steel, steel is dependent on the supply of iron, the supply of iron is dependent on steam trains, steam trains are dependent on steam engines etc. All these converted converters belong to the world as converted converter. Also human beings belong to the world as converted converter as the one who converts, consumes and enjoys these converted converters. In other words, the world as converted converter concerns the whole of the natural, artificial and social environment, i.e. our being-in-the-world. With this, Aristotle's classical characteristic of the movedness (kinesis) of the phusis receives a new meaning, namely in terms of converted converter.

What is the relation between the world as converted converter and the invention of the steam engine as a particular converter of energy? It is questionable whether the steam engine as energy converter could have been invented if the world still appeared as immobile and locally embedded object. The World as immobile and locally embedded object might lead to all kinds of artifacts to dig and chop these objects and build houses and infrastructures for instance, but not to technologies to convert energy. The world as converted converter grounds the invention of the steam engine and the subsequent disruption of the socio-economic world order due to the introduction of steam power in our society. Why? The invention of the steam engine at an ontic level is dependent on the world as converted converter at an ontological level; without the appearance of the world as converted converter, no steam engine as such a converter of coal into steam power could have been invented or even be called for. The world as converted converter grounds the invention of the steam engine, as this world is the origin from which the invention of the steam engine as such a converter of energy arises.

\footnotetext{
${ }^{4}$ We reserve the word converted converter for the appearance of the World in the Anthropocene, and do not apply it to the transformation of the appearance of the world. What is at stake in the invention of the steam engine is the transformation of the ontological pattern of the meaning of the world, resulting in a world that is pattered as converted convertor. Although we have the tendency to understand everything in terms of the world as converted converter, the transformation that leads to this new appearance of the world cannot itself be understood in terms of a conversion as the World as converted converter follows from this transformation.
} 
Although the world as converted converter grounds the invention of the steam engine, it is not the subject or cause of this invention. The appearance of the world as converted converter has not always been around but commences with the invention of the steam engine, its dissemination and its further development. The invention of the steam engine is not only the beginning of something new to the world that didn't exist before-e.g. steam powerbut founds the world as converted converter from which the invention of the steam engine springs forth. This founding of world by the invention of the steam engine consists in its ending a phase in world-history - the appearance of the world as relatively immobile and locally embedded material object - and in its commencement of a new phase in worldhistory-world as converted converter. ${ }^{5}$ The invention of the steam engine does not create or produce the appearance of the world as converted converter but in its creative destruction of the world as immobile and locally embedded material object, it founds the world as converted converter in which it can function properly. And yet, although the invention of the steam engine founds the world as converted converter, it is not the subject or cause of the transformation of the world. If the invention of the steam engine appeals to the world as converted converter for its proper functioning, it is indeed not the artefact at an ontic level that is the cause of the transformation of world at an ontological level, nor is this world the ontological effect of the technological invention of the steam engine. In other words, the invention of the steam engine founds the appearance of the world as converted converter in which it is already grounded.

With this, it becomes clear that the cause-effect relation between the invention of the steam engine as energy converter and the appearance of the world as converted converter in inapplicable, as they are interdependent and co-constitutive for each other. The invention of the steam engine belongs within the world its invention opened up. ${ }^{6}$ The world as converted converter establishes a temporal stable environment in which the invention of the steam engine as energy converter is grounded. At the same time, it is the invention of the steam engine which founds this world as converted converter. In this regard, the invention of the steam engine is not only grounded in the world as converted converter, but reaches ahead beyond its grounding in the world by founding this world as converted converter in which it has its ground. The ontological impact of the invention of the steam engine on world-constitution is ontologically first, but not necessarily in the temporal sense of the word (Blok, 2021b). ${ }^{7}$ Philosophical reflection on the role of technology in the Anthropocene should not unilaterally reflect on new emerging technologies like the steam engine and how they change the socio-economic world order, or on the appearance of the world as converted converter at an ontological level, but exactly on this interplay between the founding and grounding of world that is at stake in the invention of the steam engine. If we talk about the

\footnotetext{
${ }^{5}$ This distinction between the beginning of something new at an ontic level and the commencement of world at an ontological level is inspired by Heidegger (2014: 3).

${ }^{6}$ In this regard, the discussion whether the invention of the steam engine is necessary but also sufficient condition for the emergence of the world as converted convertor is inappropriate. The steam engine is not claimed to be such a cause. On the one hand, in the history of technological evolution, several authors have indicated the significant role of the invention of the steam engine in the emergence of an entirely new world, ranging from Schumpeter to Kondratieff. On the other hand, the interplay between founding and grounding of the world as converter converter makes it impossible to designate the steam engine as the principle agent in this transition.

${ }^{7}$ We concentrate here on the world-constituting capacity of technology, i.e. the role of technology in the constitution of our being-in-the-world, and omit the further analysis of the role of economic and political factors that play a role in world constitution, as this is beyond the scope of this article.
} 
founding of World in the remainder of this article, we mean this interplay between founding and grounding that constitutes World.

The interdependency of the invention of the steam engine and the appearance of the world as converted converter shows that this world is not founded once and for all with the invention of the first steam engine. The founding of the world as converted converter is only performatively constituted in the repetitive appropriation of its grounding in its dissemination and further development in the world as converted converter. We speak of a repetitive appropriation, as the world as converted converter is only grounded through the repetitive embodiment of this world in the dissemination and further development of the steam engine; the world as converted converter includes particular possible developments - e.g. the invention of the steam digester as a more efficient energy converter which remains grounded in the world as converted converter-while it at the same time excludes other possible developments - a return to the world as immobile and locally embedded material objects for instance. We speak of a repetitive appropriation as the founding of the world as converted converter is only appropriated in actual dissemination and improvement practices.

The world as converted converter is ontologically first as it determines what can be achieved within this world, and what not. Contrary to the appearance of the world as immobile and locally embedded material object, the world as converted converter gives rise to questions about the optimisation and efficiency of current conversion practices. This leads to particular new inventions like the steam digester and to the improvement of steel production for railroads and stronger locomotives, which in turn enables the intensification, acceleration and expansion of the conversion of natural and human converters to build our global industrial society today. It is in this respect, that we can say that the commencement of the world as converted converter comes ontologically first, but only comes to the fore and appears in the course of the subsequent inventions and their further dissemination and development.

We can experience this concretely in the development of thermodynamics. As the energy conversion efficiency of the steam engine is relatively low, the establishment of the world as converted converter by the invention of the steam engine calls for instance for new inventions of new energy converters (e.g. electricity) and subsequent technological developments. It also leads to the development of thermodynamics, starting with studies to improve the efficiency of the steam engine, but since then evolving to the study of nature in theoretical physics and the Earth system today (Kleidon, 2016). Thermodynamics reveals that the world as converted converter can be further characterized by the strife between entropy or disorder and negative entropy or order. On the one hand, the conversion of water to steam power, steam power to mobility, mobility to bricks, bricks to buildings, buildings to cities etc. shows that beings in the world are converted to negative entropy or negentropic concentrations that populate the world as trees and houses, humans and non-humans. On the other hand, as every conversion of energy is accompanied by the loss of useful energy, every being-in-the-world as converted energy is the product of a battle against the loss of energy in the process of conversion. And to the extent that this battle will always turn out to be in vain, each and every negentropic world order as converted energy will be temporary and ultimately converted back into disorder and chaos. In the world as converted converter, both natural and human resources appear as forwardly converted converter to differentiate higher levels of negentropic order (steam-mobility - worker-bricks - buildings - cities etc.), which will in the end be converted backwards due to entropic disintegration. The 
world as converted converter is characterized by the simultaneous strife between entropy (backward conversion toward disorder) and negentropy (forward conversion toward order), which means that the steam engine, just like each and every being in the world, substantiates this strife.

\subsection{The Contribution of the Ontology of Technology to Contemporary Debates in Philosophy of Technology}

Our analysis of the role of technological inventions in the constitution of world enables us first of all to confirm the first hypothesis we developed in section one. The simultaneous destruction and constitution of world by the invention of the steam engine is not primarily in the hands of a world-making capacity of humanity. It is not humanity that commences the world as converted converter, as humanity is primarily included in this world as a particular converter of energy. But this does not imply that only an external factor, like God or a destiny, can commence the commencement of world, as Heidegger would argue (Heidegger, 2014: 3). On the contrary, the example of the steam engine shows that it is primarily the technological invention of the steam engine that founds the world as converted converter, in which human being-in-the-world is primarily included. The human being is not the subject of the world as converted converter, as this world shapes our existence and action.

When we highlight the role of technological invention in the constitution of world, we do not mean that technology overcomes humanity (Nietzsche, 1988: 14), and that there is no role for human interventions. As we have seen, world is performatively appropriated in the repetition of its founding-grounding of the world as converted converter, to which human beings are primarily responsive in their action and behaviour. Although humanity is not the subject of world-constitution, he is also not merely the object of this world. On the one hand, the transformation of the world as converted converter involves the transformation of human being as relatively immobile and locally embedded subject to human being as mobile and non-local energy converter. On the other hand, it is only in our actual engagement in action and behaviour as energy converters and in the dissemination and further improvement of the steam engine that the world as converted converter is performatively founded. In other words, humanity is a necessary condition for the appropriation of our being-in-the-world. With this notion of the responsiveness of human being, we keep on the one hand the question open whether humanity is absorbed by its technological determination. Technological inventions like the steam engine found world and this world constitution by technological inventions is not without human responsiveness to this world. With this, it is not necessarily implied that humanity is completely absorbed in its technological determination. ${ }^{8}$ We do on the other hand not deny the involvement of human beings in the founding of the world as converted converter, but we reject anthropocentric orientation of the world-making power of humanity based on our analysis. ${ }^{9}$ Our analysis of the role of technological invention in the founding of the appearance of world enables us secondly to substantiate our second hypothesis that technological inventions at an ontic level have an ontological impact and constitute world at an ontological level.

\footnotetext{
${ }^{8}$ We have argued that humanity is not or not only absorbed by technology, but remains embedded the natural environment of Earth and World (Blok, 2021c).

9 The further analysis of the particular role of human being in the technological inventions is beyond the scope of this article.
} 
We finish this section by considering the contribution of our ontology of technology to contemporary debates in philosophy of technology.

First, contrary to philosophers of technology like Don Ihde, who concentrate on the ontic mediation and world-shaping of technology, we have seen that technological inventions at an ontic level mediate the world at an ontological level. The invention of the steam engine does not only found a new reality at the ontic level of a new artefact or at the level of a new socio-economic reality, but has an ontological impact as it founds the world as converted converter in which this technology, its dissemination and further development remains grounded. Contrary to philosophers of technology like Martin Heidegger, who concentrate on the ontological mediation and world-shaping of technology by the essence of technology, we have seen that technological inventions at an ontic level mediate world at an ontological level. The interdependency and co-constitutive nature of the invention of the steam engine at an ontic level and the world as converted converter at an ontological level provides good reasons to reject any unilateral focus on either the ontological level of technological invention - i.e. a Heideggerian approach that conceptualizes the essence of modern technology as enframing while neglecting the role of technological inventions like the steam engine at an ontic level - or on the ontic level of technological invention-i.e. a post-phenomenological approach that conceptualizes how the invention of the steam engine creates a new socio-economic reality while neglecting the ontological impact on the world as the whole of being that appears from now on as converted converter. ${ }^{10}$ Our reflections on the ontological impact of the invention of the steam engine provide good arguments to rehabilitate the ontic-ontological difference that was rejected by post-modernist philosophy of technology, e.g. Ihde's idea that there is no Heideggerian 'essence' of technology beyond the many technologies (Ihde, 2010) and Latour's idea of a flat ontology in which no room is left for an ontological concept of world (Latour, 2016). At the same time, our reflections on the ontological impact of the invention of the steam engine provides good arguments to reject Heidegger's abstract and essentialist explanation of the technological world. World as converted converter is not destined by an abstract essence of technology, as Heidegger would argue, but founded by the invention of the steam engine. ${ }^{11}$

Second, the ontological impact of a technological invention like the steam engine consists in its destruction of the world as relatively immobile and locally embedded material object that can be transformed by technology (e.g. stone, bronze, iron), and its simultaneous founding of a new world in which the environment appears as relatively mobile and non-local converted converter (e.g. steam, electricity). This 'creative destruction' of world is not primarily economic (Schumpeter, 1983), but concerns the appearance of the world as a whole in which we are always already intentionally involved and which constitutes

\footnotetext{
${ }^{10}$ Even if Ihde agrees with Heidegger's diagnosis of technology in Heidegger's technologies, he claims that this diagnosis does not hold for the whole of being but only for particular gigantic technologies such as power plants. He in fact criticizes Heidegger for extrapolating his diagnosis of particular technologies to all technologies (Ihde, 2010). With this, Ihde does not only miss the methodological point of departure of Heidegger's diagnosis, which doesn't start from beings but remains at the level of Being. With this, Ihde also misses the point that technological inventions have an ontological impact on the world as the whole of being.

${ }^{11}$ If we concentrate on world-constitution by technologies in this article, we do not deny that socio-economic factors like patent structures and commercial or military interests may advance or block technological development. We also do not want to argue that world can only and exclusively be constituted by technology, and keep open the possibility of world-constitution by concepts or ideas, works of art and scientific theories etc. The further elaboration of the relation between technologies and other sources of world-constitution is beyond the scope of this article.
} 
a meaningful interior milieu of meaning for our being-in-the-world $(\S 1)$. The rehabilitation of an ontological concept of world in philosophy of technology helps to consider the underlying assumptions and conditions associated with particular technologies that lead to the technological society we live in today. Furthermore, the ontological concept of world may provide an appropriate starting point to consider the planetary oikos housing these technologies, which is threatened by these technologies today (Zwier \& Blok, 2017). Finally, the ontological concept of world may provide the objective to think a post-Anthropocene world to surmount climate change as destructive side effect of technological progress in our technological society.

Third, our analysis provides good reasons to take a step back and to criticize a Heideggerian diagnosis of the age of modern technology. According to Heidegger, the age of modern technology is characterized by a mutual challenging forth of humanity and nature, i.e. by the omni-presence of being for thinking in its continuous exploitation and use. We can criticize Heidegger, however, as the world as converted converter is not characterized by the omni-presence of being for thinking, but by the strive between negentropy-forwardly converted converters, which might be associated with Heidegger's omni-presence of being for thinking - and entropy, i.e. the intrinsic tendency to the dissolution of each and every presence. This means that being and thinking are not omni-present but entropic. ${ }^{12}$ The strife between entropy and negentropy that constitutes our being-in-the-world as converted converter remains unthought in Heidegger's conceptualization of the age of modern technology (Stiegler, 2021; Blok, 2019). We can frame the difference in the following way: while for Heidegger, beings emerge fully as themselves in the omnipresence of Enframing, for us, beings emerge as converted converter, i.e. not as themselves but always other than themselves. $^{13}$

Fourth, we have seen that the constitution of world comes in waves. This means that the constitution of a new world order by the invention of the steam engine is accompanied by the destruction of an existing world. This opens first of all a new perspective on the revolutionary nature of disruptive technologies. The invention of the steam engine is revolutionary, as it can no longer be thought out of the world as relatively immobile and locally embedded material object. This invention destabilizes and in the end destructs the world as relative immobile and locally embedded material object by mobilizing each and every natural and human resource. As such, the invention of the steam engine founds a radically new reality as mobile and non-local energy, in which the world appears as converted converter. The revolutionary nature of a disruptive technology like the steam engine consists in the transformation of the world as a whole - world as immobile and locally embedded material object, world as converted converter - that the invention of the steam engine brings about in advance. We call this the emancipatory potential of new and emerging technologies.

But if technological inventions found world, this means that we cannot blame modern technology for the destruction of the pre-modern world, as Heidegger would argue. All technological inventions can potentially destruct and construct world, including pre-modern technologies. With this, we do not mean that pre-modern technologies already disclose the

\footnotetext{
12 In an earlier contribution, I mistakenly associated the strive between entropy and negentropy with Heidegger's conception of the truth of being (Blok, 2021c). In fact, thermodynamics characterizes the world founded by the invention of the steam engine, not the process of world-creation (Blok, 2021b).

13 To convert means to change into another (use, form, substance, destination etc.), to transform: from com (together, with) + wer- (to raise or lift, to turn or bend).
} 
world as standing reserve for our exploitation, as Peter-Paul Verbeek would argue (Verbeek, 2005: 69). Contrary to such an a-historical perspective on pre-modern technology, we argue for a radical historical perspective on the potential ontological impact of technological inventions on world constitution. With this, we do not only reject Heidegger's a-historical perspective on pre-modern technology. His idea that the tool (e.g. a hammer, a pen) appears in its serviceability and usability as equipment in order to hammer, to write etc. is not a-historical and subsequently destructed by modern technology. ${ }^{14}$ On the contrary, we can argue that the world as equipment is embedded in the world as converted converter, as only in the world as converted converter, beings are only discussed in terms of their 'serviceability' and 'usability'. Only in the world as converted converter, there is no material, temporal and geographical constraint and is everything ready at hand for our practical engagements in the world (Heidegger, 1993: 66-69). The world as converted converter grounds both Heidegger's 'original' world of equipment and its deviation in modern technology, i.e. enframing.

The radical historicity of technology provides also a new perspective on future waves in world-founding by technological innovations. If the ontological impact of technological inventions on world-founding comes in waves, we have to reject the unique position Heidegger ascribes to modern technology. According to Heidegger, the supreme danger involved in modern technology is that humanity "everywhere and always encounters only" him or herself and is no longer aware that technology mediates our experience of world at an ontological level (Heidegger, 1977: 27). For this reason, he argues in his late Spiegel interview that only a God can save us. But if the invention of the steam engine destructed the world as relatively immobile and locally embedded material object, new and emerging technologies might destruct the world as relatively mobile and non-local converted converter in the future. We don't have to rely on God to disrupt the world of enframing, because new and emerging technologies have the principal possibility to destruct the world as converted converter in the future.

Fifth, this conceptualization of the world-founding capacity of technological inventions limits any monolithic and deterministic understanding of the technological world, as the emergence of new technologies at an ontic level may always involve the destruction of the existing world. The principal possibility of the transformation of the world due to technological inventions enables us be less pessimistic or even fatalistic about the technological world, like Jaspers, Ellul and Heidegger. Of course, geoengineering and synthetic biology may embody the greatest danger for human and non-human survival in the world. At the same time, new technologies might be invented that disrupt the world as converted converter and constitute a new world in the future. We call this the emancipatory potential of technological inventions, that repetitively appropriate the world in which they are grounded on the one hand, but can also potentially disrupt the existing world and found a new world like the steam engine once did on the other.

In the next section, we consider these contributions of our non-anthropocentric, nonessentialist and non-determinist ontology of technology in light of the discussion of the world-historical significance of climate change.

\footnotetext{
${ }^{14}$ It is increasingly acknowledged that there is a continuum between Heidegger's proto-technological metaphysics of equipment in order to... in Being and Time and his later analysis of technology as challenging forth... (Dreyfus, 1991: 175). The further analysis of this continuum is beyond the scope of this article (see Blok 2014).
} 


\section{Conclusion: The Role of Technological Invention in the Constitution of the Post-Anthropocene World}

Our analysis in the previous section also opens a new perspective on the emergence of the Anthropocene world in which we live today, the prospects of a post-Anthropocene world and the role of humanity in this process. While in the introduction, we introduced the world-historical significance of climate change, as it disrupts the relative stability of our being-in-the-world in the Holocene and inaugurates a geological era of relative instability in the Anthropocene, the previous section provides good reasons to argue for the ontological impact of the invention of the steam engine on the constitution of the Anthropocene world; the invention of the steam engine has world-historical significance, as its invention on an ontic level has an ontological impact on the constitution of the world at an ontological level. The invention, dissemination and further development of the steam engine destructs the world as immobile and locally embedded material object—which we can associate with the relative stability of our being-in-the-world in the Holocene-and simultaneously constitutes a new world as relatively mobile and non-local converted converter-which we can associate with the relative instability of our being-in-the-world in the Anthropocene. This means that the starting point of the Anthropocene does not only coincide with James Watt's design of the steam engine in $1784(\S 1)$, but is founded by this invention.

While in section one, the newness of the Anthropocene world was found in the rivalry between the untameable natural and human forces (Hamilton, 2017), the previous section enables us to conceptualize the relative instability of the Anthropocene world in terms of the strife between entropy (disorder) and negentropy (order) that constitutes our being-inthe-world as converted converter. In first instance, only the progressive or negentropic tendency towards the omni-presence of being for thinking was highlighted in what we now call the Anthropocene world, as in Heidegger's notion of enframing. Nowadays the entropic tendency toward disorder, which is observable in the inherent instability of the climate and volatility of the Earth system (Clark, 2011), is no longer deniable. This strife between entropy and negentropy explains also the fundamental uncertainty about the future impacts of technological developments, as each and every potential contribution to forward entropy (order) will turn out to be a contribution to backward entropy (disorder).

Our analysis in the previous section also enables us to conceptualize the role of humanity in the constitution of the Anthropocene world. Humanity is not the subject of world-making $(\S 1)$, as the invention of the steam engine primarily constitutes the Anthropocene world in which being and thinking appear as converted converters $(\$ 2)$. At the same time, the repetitive appropriation of the Anthropocene world in the invention, dissemination and further development of the steam engine shows that the constitution of world is also not without human being-in-the-world as particular energy converter, who contributes to this repetitive appropriation. The Anthropocene world is not established once and for all by the invention of the steam engine, but is founded by the invention, dissemination and further development of this technology, in which humanity as specific converter of energy is involved. In this regard, we can acknowledge humanity as dominant geopower in the Anthropocene world and acknowledge the includedness of the human being as particular energy converter in the world as converted converter, without presenting humanity as subject or world-making capacity. The Anthropocene world grows out of the invention, dissemination and further 
development of the steam engine at the beginning of the industrial revolution, with increasing climate change as a destructive side effect of technological progress.

This brings us back to our question about the need for a post-Anthropocene world in times of climate change. Does our analysis in the previous section provide any prospects of a post-Anthropocene world? Although we rejected the world-making capacity of both humanity and God (\$2), our analysis provides good reasons to be positive about the prospects of a post-Anthropocene world. The Anthropocene world has not always been there, but is founded by the invention of the steam engine, its dissemination and further development in the course of history. As all technological inventions can potentially destruct and constitute world, new and emerging technologies may no longer be thought out of the Anthropocene world as converted converter, may destruct the Anthropocene world as converted converter and in the end found a new post-Anthropocene world in which these technologies are grounded.

The invention of the steam engine is followed by subsequent inventions like the combustion engine. On the one hand, these subsequent inventions can be understood out of the world as converted converter, for instance the combustion engine as more efficient energy converter. In this case, these inventions do not destabilize but reinforce and entrench the existing world as converted converter. On the other hand, we have to keep open the principal possibility that these subsequent inventions destabilize and emancipate the existing Anthropocene world and inaugurate the transformation to a new post-Anthropocene world. In case of the combustion engine for instance, we can straightforwardly argue that the Anthropocene world as converted converter is reinforced and entrenched; we can neither argue that the combustion engine destabilizes the existing world as converted converter, nor that it constitutes a new world, as it primarily appears as a more efficient energy converter. In other cases, however, technological inventions are more ambiguous. Nuclear energy for instance can be seen as a technological development towards more efficient energy converters. On the one hand, nuclear power can be seen as reinforcing the Anthropocene world as converted converter. But on the other hand, the nuclear waste accompanying the generation of nuclear energy may no longer rely on world as mobile and non-local converted converter and destabilize this world. In a way, nuclear waste is immobile and locally embedded, as we have to keep it 'forever' safe in particular locally designed and guarded dump places. While nuclear energy still seems to rely on the world as mobile and non-local converted converter, nuclear waste destabilizes this world as it is fundamentally immobile and locally embedded. Nonetheless its immobility and local embeddedness, the possible leakage of nuclear waste threatens the world as a whole. ${ }^{15}$

We don't want to decide here whether nuclear power in fact reinforces and entrenches the Anthropocene world, or already provides an indication to a post-Anthropocene world. This would require a dedicated analysis of these technologies and their ontological impact. For the purposes of this article, however, the example is sufficient to make three things clear. First, while the world-historical significance of the invention of the steam engine consists in its founding of the Anthropocene world, this world is principally open ended towards the future. The Anthropocene world as converted converter is only founded by

\footnotetext{
15 This might be seen as a main difference between the previous wave associated with water power, which still relies on the world as relatively immobile and locally embedded (\$2). While both water power and nuclear waste can be seen als relatively immobile and locally embedded, the first only has local and relatively short-term impacts, while the latter potentially has global and eternal or at least long-term impacts.
} 
its repetitive appropriation in subsequent developments, like the invention of the combustion engine etc. In the process of repetitive appropriation, new technological developments emerge - like solar energy and digital technology today - that either reinforce and entrench the existing world as converted converter, and therefore continue the Anthropocene world, or destruct this world and open the perspective of the post-Anthropocene world. Each and every technological invention has this emancipatory potential-we may even frame it as positive freedom - to move beyond its reinforcing and continuing the Anthropocene world and to inaugurate a new post-Anthropocene world. Second, this open endedness of world implies that the ontological impact of technological inventions does not primarily consists in the regulation of the world and our human being-in-the-world, as philosophers like Ellul would argue, but opens possibilities for completely different arrangements of our human being-in-the-world in the future. It enables us to move beyond techno-optimism and techno-pessimism, beyond techno-conformism and techno-non-conformism, and beyond techno-determinism and techno-constructivism, and enables us to concentrate on the principle variability and openness of technological invention. Third, to the extent that the post-Anthropocene world can only be grounded by its repetitive appropriation, human being-in-the-world is actively involved in the exploration of this emancipatory potential. Only in the active experimentation with the emancipatory potential of new and emerging technologies, a post-Anthropocene world can be performatively constituted. So, although not the subject of world-making, humanity is not enslaved by the technological world of the Anthropocene, in which no sign of a post-Anthropocene world can be found and only a God can safe us. On the contrary, the post-Anthropocene world can only emerge in the repetitive appropriation of this emancipatory potential of technological inventions via our active experimentation with this potential. Although the practical and normative dimension of the active experimentation with the emancipatory potential of new and emerging technologies requires dedicated reflection in future contributions, it is safe to say that our human involvement in the invention, dissemination and further development of technologies define us as moral beings. In order to fully understand the morality of the human involvement in technological inventions, we should consider the nature of creativity involved in such inventions in future research.

The emancipatory potential of new and emerging technologies to inaugurate the postAnthropocene world provides an alternative for a pessimist philosophy of technology. The destructive side effects of technological progress is clear enough today, but instead of technological fatalism, the emancipatory potential of new and emerging technologies calls for a reflexive imaginary to inaugurate the post-Anthropocene world in which the sustainability of the life support systems of planet Earth receives our attention. One particular progressive development in this regard is the concept of biomimetic technology (Blok \& Gremmen, 2016). Biomimetic technologies imitate operating principles of nature, like 'nature runs on sunlight', 'nature recycles everything' in technological design (Benyus, 2002) and provide an alternative for the destructive side effects of technological progress that is characteristic of the Anthropocene world. Like in the case of nuclear energy, we leave the question open here whether biomimicry merely reinforces and entrenches the Anthropocene world-by introducing a regenerative converted converter-or paves the way to a post-Anthropocene world (Blok, 2017). It functions here as example of our progressive understanding of the ontology of technology, which engages philosophers of technology to reflect on the ontological impact of technological inventions, and to this end, consider the emancipatory potential 
of new and emerging technologies at an ontic level as well. Only such an engagement in the ontic-ontological analysis of new and emerging technologies enables us to move beyond an abstract and monolithic understanding of technology, and beyond anthropocentrism and determinism in our consideration of our contribution to the emergence of the post-Anthropocene world. ${ }^{16}$

Funding Information This work is part of the research programme Ethics of Socially Disruptive Technologies, which is funded through the Gravitation programme of the Dutch Ministry of Education, Culture, and Science and the Netherlands Organisation for Scientific Research under Grant number 024.004.031.

\section{Declarations}

This paper is a conceptual paper authored by a single author. There are no ethical issues involved, all responsibilities lie with the single author. Also, there are no conflicts of interest involved.

Open Access This article is licensed under a Creative Commons Attribution 4.0 International License, which permits use, sharing, adaptation, distribution and reproduction in any medium or format, as long as you give appropriate credit to the original author(s) and the source, provide a link to the Creative Commons licence, and indicate if changes were made. The images or other third party material in this article are included in the article's Creative Commons licence, unless indicated otherwise in a credit line to the material. If material is not included in the article's Creative Commons licence and your intended use is not permitted by statutory regulation or exceeds the permitted use, you will need to obtain permission directly from the copyright holder. To view a copy of this licence, visit http://creativecommons.org/licenses/by/4.0/.

\section{References}

Benyus, J. (2002). Biomimicry: innovation inspired by nature. New York: Harper Perennial

Blok, V. (2014). "Being-in-the-world as Being-in-nature. An ecological perspective on Being and Time". Studia Phaenomenologica XIV:215-236

Blok, V., \& Gremmen, B. (2016). "Ecological Innovation: Biomimicry as a New way of thinking and acting ecologically". Journal of Agricultural and Environmental Ethics, 29(2), 203-217. https://oi. org/10.1007/s10806-015-9596-1).

Blok, V. (2017). "Earthing Technology: Towards an Eco-centric Concept of Biomimetic Technologies in the Anthropocene". Techne: Research in Philosophy and Technology, 21(2-3), 127-149. https://doi. org/10.5840/techne201752363).

Blok, V. (2019). "Nothing Else Matters: Towards an Ontological Concept of the Materiality of the Earth in the Age of Global Warming." Research in Phenomenology, 49, 65-87

Blok, V. (2021a). "Geo-Ethics beyond Enmeshment: Critical Reflections of the Post-humanist Position in the Anthropocene". In Bohle, M., \& Marone, E. (Eds.), Geo-societal narratives-Contextualizing Geosciences (pp. 29-54). Dordrecht: Springer

Blok, V. (2021b). "What is innovation? Laying the ground for a philosophy of innovation.". Techne: research in philosophy and technology, 25(1), 72-96

Blok, V. (2021c). "The morendo of the Anthropocene. Reflections on Bernard Stiegler's The ordeal of truth". Foundations of Science, https://doi.org/10.1007/s10699-020-09763-0.

Blok, V. (2022). "The Earth means the World to me: Earth- and World-interest in times of climate change". In Di Paola, M., \& Pellegrino, G. (Eds.), Handbook of Philosophy of Climate Change. Dordrecht: Springer

Clark, N. (2011). Inhuman Nature. Sociable Life on a Dynamic Planet. Los Angeles: Sage

Crutzen, P. (2002). “Geology of mankind. ”. Nature, 415, 23. https://doi.org/10.1038/415023a)

Dreyfus, H. (1991). Being-in-the-world. A commentary on Heidegger's Being and Time, Division I. Cambridge: MIT press

Ellis, E. (2011). "The planet of no return. Human resilience on an artificial earth.” Breakthrough Journal, 2, $37-44$

${ }^{16}$ I would like to thank Jochem Z wier and Ole Thijs for their fruitful comments on section two of this article. 
Figes, O. (2019). The Europeans: Three Lives and the Making of a Cosmopolitan Culture. New York: Metropolitan Books

Hamilton, C. (2017). Defiant Earth. The Fate of Humans in the Anthropocene. Cambridge: Polity

Heidegger, M. (1977). The Question concerning technology and other essays. New York: Harper and Row

Heidegger, M. (1993). Sein und Zeit. Tübingen: Max Niemeyer Verlag

Heidegger, M. (2014). Hölderlin's Hymns “Germania” and "The Rhine”. Bloomington: Indiana University Press

Hilbert, M. (2020). "Digital technology and social change: The digital transformation of society from a historical perspective." Dialogues in Clinical Neuroscience, 22(2), 189-194

Ihde, D. (2010). Heidegger's technologies. Postphenomenological perspectives. New York: Fordham

Ihde, D. (2012). Experimental phenomenology: multistabilities. Suny Press

Kleidon, A. (2016). Thermodynamic Foundations of the Earth System. Cambridge: Cambridge UP

Latour, B. (2016). "Why Gaia is not a God of Totality." Theory, Culture and Society, 34(2-3), 61-81

Lemmens, P., Blok, V., \& Zwier, J. (2017). “Toward a Terrestrial Turn in Philosophy of Technology.” Techné: Research in Philosophy and Technology, 21(2-3), 114-126

Leroi-Gourhan, A. (1945). Milieu et techniques. Paris: Albin Michel

McLuhan, M. (1964). Understanding media: the extensions of man. New York: McGraw-Hill

Marx, K. (1973). Grundrisse: Foundations of the critique of political economy. Harmondsworth: Penguin

Nietzsche, F. (1988). Also Sprach Zarathustra. Kritische Studienausgabe Band 11. München: DTV/de Gruyter

Pearce, F. (2007). The Last Generation. How Nature will take her revenge for climate change. Eden Project Books: Cornwall

Schumpeter, J. (1983). the theory of economic development. New Brunswick: Transaction publishers

Simondon, G. (2017). On the mode of existence of technical objects. Univocal: Washington

Steffen, W., Grinevald, J., Crutzen, P., \& McNeil, J. (2011). "The Anthropocene: Conceptual and Historical Perspectives." Philosophical Transactions of the Royal Society A, 369, 842-867

Steffen, W., Broadgate, W., Deutsch, L., Gaffney, O., \& Ludwig, C. (2015). "The trajectory of the Anthropocene: The great acceleration." The Anthropocene Review, 2(1), 81-98

Stiegler, B. (1998). Technics and Time 1. Stanford UP: Stanford

Stiegler, B. (2021). "The Ordeal of Truth. Causes and Quasi-Causes in the Entropocene." Foundations of Science, https://doi.org/10.1007/s10699-020-09736-3

Verbeek, P. P. (2005). What things do: Philosophical reflections on technology, agency and design. University Park: Pennsylvania State University Press

Wallace-Wells, D. (2019). The unhabitable Earth. Life after warming. New York: Tim Duggan Books

Zwier, J., \& Blok, V. (2017). "Saving Earth-Encountering Heidegger's Philosophy of Technology in the Anthropocene." Techne: Research in Philosophy and Technology, 21(2-3), 222-242

Publisher's Note Springer Nature remains neutral with regard to jurisdictional claims in published maps and institutional affiliations.

Dr. Vincent Blok is associate professor in Philosophy of Technology and Responsible Innovation at the Philosophy Group, Wageningen University (The Netherlands). In 2005 he received his $\mathrm{PhD}$ degree in philosophy at Leiden University with a specialization in philosophy of technology. Together with four PhD candidates and three Post-docs, he is involved in several (European) research projects in the field of philosophy of technology, biobased \& circular economy and responsible innovation. His books include Ernst Jünger's Philosophy of Technology. Heidegger and the Poetics of the Anthropocene (Routledge, 2017) and Heidegger's Concept of philosophical Method (Routledge, 2020). Blok published over hundred articles in high ranked philosophy journals like Environmental Values, Business Ethics Quarterly, Synthese and Philosophy \& Technology, and in multi-disciplinary journals like Science, Journal of Cleaner Production, Public understanding of Science and Journal of Responsible Innovation. See www.vincentblok.nl for more information about his current research. 